\title{
Effects of Oral pH Changes on Smoking Desire
}

\author{
Gökçen Ömeroğlu Şimşek1, Gülser Kılınç, Begüm Ergan ${ }^{1} \oplus$, Oğuz Kılınç ${ }^{1}$
}

\author{
${ }^{1}$ Department of Chest Diseases, Dokuz Eylül University, School of Medicine, İzmir, Turkey \\ ${ }^{2}$ Department of Oral and Dental Health, Dokuz Eylül University Vocational School of Health Services, İzmir, Turkey
}

Background: Nicotine addiction is associated with nicotine absorption from the buccal mucosa, and it is stated that the main factor that determines nicotine absorption is saliva $\mathrm{pH}$. In the literature, the effects of changes in saliva $\mathrm{pH}$ values after eating and drinking on smoking desire in smokers were not questioned.

Aim: To show the effect of saliva $\mathrm{pH}$ changes on smoking desire. The secondary aim was to show the impact of coffee and water drinking on saliva $\mathrm{pH}$ and smoking on oral-dental health (oral hygiene and gingival bleeding).

Study Design: Case-control study.

Methods: A questionnaire was administered that included "Sociodemographic Data Form" and smoking history and Fagerström Test for Nicotine Dependence (FTND). Oral and dental examinations were performed with mirror sonds and using oral hygiene standard Silness and Leöe plaque index and DMFT Index (Index of Decayed Missing or Filled Teeth). Untreated saliva samples were taken, and baseline saliva flow rate and $\mathrm{pH}$ values were measured. To assess $\mathrm{pH}$ changes, saliva $\mathrm{pH}$ was remeasured after sugar-free instant coffee and water consumption. Smoking desire was evaluated with the Visual Analog Scale (VAS).
Results: In this study, 24 (55.8\%) females and 19 (44.2\%) males were among the 43 smoking and 39 nonsmoking cases. Smoking was significantly associated with poor oral hygiene (in smokers $4.71( \pm 1.40)$, in non-smokers $2.30( \pm 1.59)$; $P<.01)$. DMFT index was higher in smokers than in non-smokers (in smokers $6.45( \pm 3.69)$, in non-smokers 3.87 $( \pm 2.67) ; P<.01)$. Gingival bleeding was more prevalent in smokers $(0.68( \pm 0.76))$ than non-smokers $(1.20( \pm 0.90) ; P=.009)$. Salivary flow rates were lower in smokers (in smokers $2.56( \pm 1.34)$, in non-smokers $3.00( \pm 1.22), P=.06)$. In both groups, $\mathrm{pH}$ values increased after coffee consumption and decreased after water; in smokers basal: $6.67( \pm 0.41)$, $\mathrm{pH}$ coffee: $6.93( \pm 0.36), \mathrm{pH}$ water: $6.85( \pm 0.33)$; in non-smokers $\mathrm{pH}$ basal: $6.84( \pm 0.37)$, pH coffee: $7.02( \pm 0.37)$, pH water: $6.97( \pm 0.31)$, $P<.01$. The VAS values of smokers at basal $4.73( \pm 3.21) ; P<0.01$, after coffee consumption $4.91( \pm 3.08) ; P<.01$, and after water 3.15 $( \pm 2.72) ; P<.01$.

Conclusion: The saliva $\mathrm{pH}$ increased after coffee consumption and decreased after drinking water. Besides, VAS values decreased significantly after drinking water. The results suggest that a simple behavior such as drinking water may be used in conjunction with behavioral and cognitive therapies to pursue smoking cessation.

\section{INTRODUCTION}

Nicotine addiction is the most common disease of our societies, and it can be treated with medical methods, such as other diseases. ${ }^{1}$ Pharmacotherapy with proven scientific efficacy and cognitive and behavioral treatments play an important role in reducing smoking. ${ }^{2}$ In this context, it is recommended to question the daily behavior patterns and ensure the person's motivation, identify the factors that trigger the desire to smoke, develop methods to combat them, and organize them in ordinary activities, including eating and drinking.

It can be observed that there is an increase in the desire to smoke during drinking tea and coffee and after meals. Consumption of acidic foods makes the oral $\mathrm{pH}$ acidic, and saliva increases to neutralize it. Caffeine is another psychostimulant found in varying proportions in coffee and tea, and its stimulating effects on the locomotor system are antagonistic at the level of adenosine receptors. ${ }^{3}$ It has been reported that smokers consume more caffeine than non-smokers. ${ }^{4}$ However, this effect may not be solely due to the pharmacological effects of caffeine but also that the desire to smoke is caused by a change in $\mathrm{pH}$ in the mouth. In a study by Parvinen et al., saliva $\mathrm{pH}$ was lower in smokers than in nonsmokers. ${ }^{5}$ It was also reported that saliva secretion capacities were decreased as well.

The amount of nicotine and the absorption rate from the buccal mucosa significantly affect the risk of addiction. In addition to oral

Address for Correspondence: Gökçen Ömeroğlu Şimşek, Department of Chest Diseases, Dokuz Eylül University, School of Medicine, İzmir, Turkey

e-mail: gokcen.simsek@deu.edu.tr

Received: August 20, 2020 Accepted: December 17, $2020 \bullet$ DOI: 10.5152/balkanmedj.2021.20125

ORCID iDs of the authors: G.Ö.Ş. 0000-0002-2724-0616; G.K. 0000-0002-7422-0482; B.E. 0000-0003-2920-9214; O.K. 0000-0001-8923-4476.

Available at www.balkanmedicaljournal.org

Cite this article as:

Ömeroğlu Şimşek G, Kılınç G, Ergan B, Kılınç O. Effects of oral pH changes on smoking desire. Balkan Med J. 2021; 38(3):165-170.

Copyright@Author(s)-Available online at http://balkanmedicaljournal.org/ 
$\mathrm{pH}$, other factors such as local blood flow, moisture of product and size of the surface area of the tobacco mixture, $\mathrm{pH}$ constant holding capacity, and nicotine content of tobacco may affect nicotine absorption. Various absorption-enhancing substances have been investigated to facilitate the absorption of nicotine from the buccal mucosa. It has been shown that increased $\mathrm{pH}$ (alkaline) increases the absorption and physiological effects of nicotine by buffering moist snuff products and nicotine gums to alkaline $\mathrm{pH}$. Although other factors may affect the nicotine absorption rate in the mouth, the main factor that determines the absorption rate of nicotine is stated to be $\mathrm{pH} .^{6-8}$

There are studies comparing nicotine products containing different amounts of nicotine. However, changes in saliva $\mathrm{pH}$ values after eating and drinking on smoking desire in the smokers were not questioned. The relation between pre- and post-coffee/water saliva $\mathrm{pH}$ and smoking desire has not been investigated. In this study, the main aim was to examine the effects of changes in the saliva $\mathrm{pH}$ values on smoking desire and the impact of water drinking action on the urge to smoke. The secondary aims were to show the effects of coffee and water drinking behavior on saliva $\mathrm{pH}$ and smoking on oral-dental health (oral hygiene, gingival bleeding).

\section{MATERIAL AND METHODS}

\section{Design}

This study was a case-control study. After obtaining approval from the Clinical Studies Ethics Committee (2018/09-01), smokers and non-smokers volunteers were invited to the study.

The sample size was calculated as follows. In the preliminary evaluation made before starting the study, saliva samples were taken from 5 non-smoker and 5 smoking volunteers, and $\mathrm{pH}$ was measured. Estimated saliva $\mathrm{pH}$ for the control group: 7.00, estimated saliva $\mathrm{pH}$ for the case group: 6.75 , standard deviation 0.29 ; when 0.05 margin of error and 0.9 power and possible drop-out rate were considered as $10 \%$, it was planned to enroll 35 volunteers for each group. ${ }^{9}$

The inclusion criteria were as follows: not having active disease, being between the ages of 18 and 45 years, not using antibiotics in the past 2 weeks, not using inhaler treatments, not having oral and salivary gland diseases, to be in the week after the menstrual bleeding period in women. In the control group, individuals without smoking history and any secondary smoke exposure were included. Exclusion criteria were the presence of active disease, less than 18 years or greater than 45 years of age, antibiotic use in the past 2 weeks, use of inhaler treatments, oral and salivary gland disease, menstrual irregularities in women, being in the luteal phase, pregnancy, and using hormonal therapy. ${ }^{10,11}$

\section{Data Collecting}

A questionnaire was administered that included "Sociodemographic Data Form" and smoking history and Fagerström Test for Nicotine Dependence (FTND). The scores were classified as low (0-4 points), medium (5-7 points), and high (8-10 points) according to the Turkish Ministry of Health, Fighting Tobacco Addiction Handbook for physicians. ${ }^{12-14}$

\section{Oral and Dental Examinations}

Oral and dental examinations were performed with the mirror sonds. The oral hygiene standard was estimated using the Silness and Löe plaque index. ${ }^{15}$ DMFT Index (Index of Decayed Missing or Filled Teeth ), a method for measuring present (decayed teeth) and past (missing and filled teeth) caries experiences in permanent dentition was evaluated and also, debris, calculus, and also gingival bleeding were evaluated. ${ }^{16}$

\section{Saliva Collection and $\mathrm{pH}$ Measurement Procedure}

Measurements were made at room temperature $\left(22-25^{\circ} \mathrm{C}\right)$, in a standard environment, and in the same place. Oral and dental examinations of all the participants were performed, and saliva samples were taken 3 times; the first sample, the second sample after coffee (pH: 5.5), and the third sample after water ( $\mathrm{pH}: 6.34)$, in a total of 30 minutes. Saliva flow rates and $\mathrm{pH}$ values were measured by taking saliva samples from all cases at least 1 hour after breakfast. Simultaneous Visual Analog Scale (VAS) smokers' actual smoking desire was measured (Figure 1). pH measurements were made with the table device "InoLab pH 720" (WTW, Germany). Device calibrations were made at the beginning of each measurement day and when deemed necessary.

\section{Visual Analog Scale}

VAS is used to assess the current smoking desire. Participants put a vertical mark on a $100 \mathrm{~mm}$ line with "no desire to smoking" on the far left and "an excessive desire to smoking" on the far right. Measurements were made with the help of a ruler and evaluated with numbers between 0 and 10 . The signs put by the participant at baseline, after coffee, and after drinking water was evaluated as increased or decreased according to whether they were on the right or left and with numerical values. ${ }^{17,18}$

\section{Statistical Analysis}

In this study, assuming a 0.05 margin of error and 0.9 power and a possible drop-out rate of $10 \%, 35$ volunteers were planned for each group. Forty-three volunteers in the case group and 39 volunteers in the control group were included. Continuous variables according to distribution analysis mean \pm standard deviation (SD) or medianinterquartile range (IQR); categorical variables were presented as numbers and percentages. The Student's $t$-test was used to analyze the significance of independent continuous variables within and between groups. In binary analysis, Chi-square and Mann-Whitney $U$-test were used depending on the distribution of data. $P$ value $<0.05$ was considered statistically significant.

\section{RESULTS}

Forty-three smokers were included in the case group, and 39 nonsmokers were included in the control group (Table 1). The most common reason for starting smoking was stress $(22 \%)$. The second most common causes were curiosity (13.4\%), followed by wannabe $(12.2 \%)$. When the factors triggering smoking requests were questioned, the most frequently stated factor was after meals 


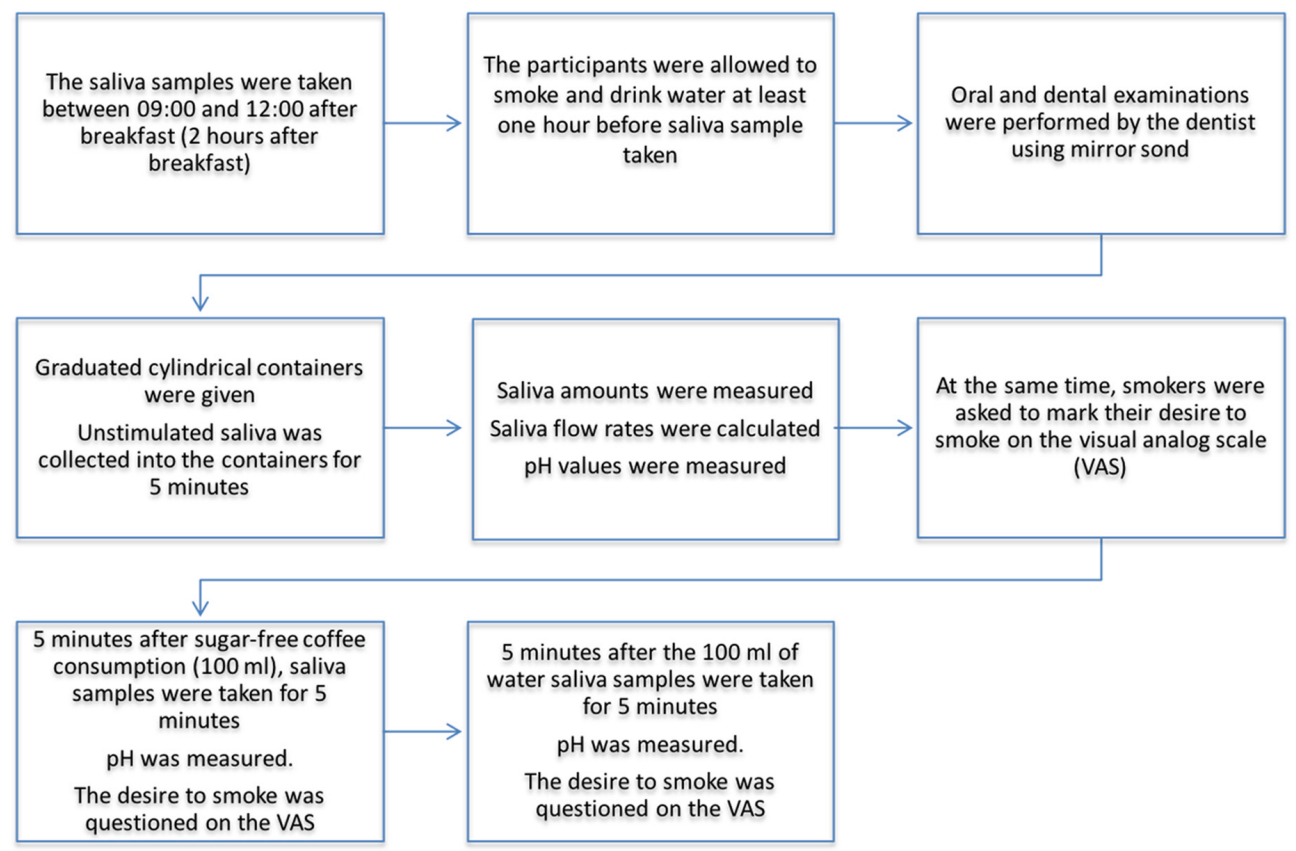

FIG. 1. Saliva collection and $\mathrm{pH}$ measurement procedure.

(37.8\%). In addition, stress (29.3\%), ambience (27.9\%), alcohol $(22 \%)$, coffee $(19.5 \%)$, and tea $(18.3 \%)$ were other trigger factors.

The oral hygiene scores, DMFT values, debris and calculus scores, and gingival bleeding values of the case and control groups are summarized in Table 2. Smoking was significantly associated with

TABLE 1. General Demographic Features of Patient Population

\begin{tabular}{|c|c|c|c|}
\hline & Smokers, $n(\%)$ & Non-smokers, $n(\%)$ & $P$ \\
\hline Age, year, mean (SD) & $32.76(9.38)$ & $28.74(9.55)$ & .056 \\
\hline \multicolumn{4}{|l|}{ Gender, $n(\%)$} \\
\hline Female & $24(55.8)$ & $29(74.4)$ & \multirow[t]{2}{*}{.079} \\
\hline Male & $19(44.2)$ & $10(25.6)$ & \\
\hline Married, $n(\%)$ & $20(46.5)$ & $15(38.5)$ & .462 \\
\hline \multicolumn{4}{|l|}{ Education, $n(\%)$} \\
\hline Primary education & $10(23.3)$ & $5(12.8)$ & \multirow[t]{5}{*}{.326} \\
\hline High school & $15(34.9)$ & $18(46.2)$ & \\
\hline University & $11(25.6)$ & $7(17.9)$ & \\
\hline Master degree & $7(16.3)$ & $7(17.9)$ & \\
\hline $\mathrm{PhD}$ & - & $2(5.1)$ & \\
\hline \multicolumn{4}{|l|}{ Occupation, $n(\%)$} \\
\hline Cleaning staff & $7(16.3)$ & $3(7.7)$ & \multirow[t]{7}{*}{.307} \\
\hline Patient care staff & $7(16.3)$ & $2(5.1)$ & \\
\hline Management staff & $3(7)$ & $4(10.3)$ & \\
\hline Nurse & $6(14)$ & $3(7.7)$ & \\
\hline Physician & $6(14)$ & $8(20.5)$ & \\
\hline Student & $10(23.3)$ & $16(41)$ & \\
\hline Other & $4(9.3)$ & $3(7.7)$ & \\
\hline
\end{tabular}

poor oral hygiene $(P<.01)$. DMFT values were higher in smokers than in non-smokers $(P<.01)$. "M" datas indicating missing teeth were analyzed, and it was observed that there was more tooth loss in the smoker group compared to the non-smoker group (in smokers $2.62( \pm 3.08)$, in non-smokers $0.58( \pm 1.18), P<.01)$. Also, debris and calculus values were higher in smokers than in nonsmokers, and gingival bleeding was more prevalent in non-smokers than in smokers $(P=.009)$.

The saliva flow rates, saliva $\mathrm{pH}$ values and changes in the case and control groups, and VAS values in smokers are summarized in Tables 3 and 4. Although it was not statistically significant, salivary flow rates were lower in smokers $(P=.06)$. The smokers' basal saliva $\mathrm{pH}$ values were lower than the non-smokers, but it was not statistically significant $(P=.104)$. In both groups, $\mathrm{pH}$ values increased after coffee consumption and decreased after water, and this is shown in Figure 2. The changes between $\mathrm{pH}_{\text {basal }}$ $(\mathrm{pH} 1)$ and $\mathrm{pH}_{\text {coffee }}(\mathrm{pH} 2)(P<.01), \mathrm{pH}_{\text {coffee }}(\mathrm{pH} 2)$, and $\mathrm{pH}_{\text {water }}(\mathrm{pH} 3)$ $(P=.019)$ were significant as summarized in Table 4 . The VAS values of smokers at basal $4.73( \pm 3.21)$ (VAS1), after coffee consumption $4.91( \pm 3.08)(\mathrm{VAS} 2)$, and after water $3.15( \pm 2.7)$ (VAS3) (Figure 3). The change between basal-VAS1 and after coffee-VAS2 was not statistically significant, but the difference between after coffee-VAS2 and after water-VAS3 was statistically significant $(P<.01)$ (Table 4$)$.

\section{DISCUSSION}

In this study, it was observed that the basal saliva $\mathrm{pH}$ values of the smokers were lower than non-smokers, and the $\mathrm{pH}$ of saliva increased after drinking an acidic beverage (pH 5.5) such as coffee. The $\mathrm{pH}$ of saliva decreased after drinking water in both groups. 
TABLE 2. Oral Hygiene, DMFT, Debris, Calculus, and Gingival Bleeding in Smokers and Non-smokers

\begin{tabular}{lccccc}
\hline & Oral Hygiene & DMFT & Debris & Calculus & Gingival Bleeding \\
\hline Smokers, mean (SD) & $4.71( \pm 1.40)$ & $6.45( \pm 3.69)$ & $2.86( \pm 0.93)$ & $1.79( \pm 0.77)$ & $0.68( \pm 0.76)$ \\
Non-smokers, mean (SD) & $2.30( \pm 1.59$ & $3.87( \pm 2.67)$ & $1.52( \pm 1.13)$ & $1.06( \pm 0.98)$ & $1.20( \pm 0.90)$ \\
$P$ & $<.01$ & $<.01$ & $<.01$ & $<.01$ & .009 \\
\hline
\end{tabular}

TABLE 3. Saliva Flow Rate and $p H$ Values of Smokers and Non-smokers

\begin{tabular}{|c|c|c|c|c|c|}
\hline & Saliva Flow Rate & pH Basal Saliva & pH After Coffee & pH After Water & $P$ \\
\hline Smokers, mean (SD) & $2.56( \pm 1.34)$ & $6.67( \pm 0.41)$ & $6.93( \pm 0.36)$ & $6.85( \pm 0.33)$ & $<.01$ \\
\hline Non-smokers, mean (SD) & $3.00( \pm 1.22)$ & $6.84( \pm 0.37)$ & $7.02( \pm 0.37)$ & $6.97( \pm 0.31)$ & $<.01$ \\
\hline$P$ & .06 & .104 & $<.01$ & $<.01$ & \\
\hline
\end{tabular}

The changes between $\mathrm{pH} 1$ and $\mathrm{pH} 2$ and the changes between $\mathrm{pH} 2$ and $\mathrm{pH} 3$ were significant. Differences were observed in the VAS values that we used to evaluate the smoking desire. Changes were observed in the VAS values we used to assess the smoking desire. The difference between VAS1 and VAS2 was not observed significantly, but the difference between VAS2 and VAS3 was statistically significant. Also, it was observed that salivary flow rates were lower in smokers. As a result of evaluations for oral health, it was observed that smoking was significantly associated with poor oral hygiene. DMFT values were higher in smokers than in nonsmokers. Debris and calculus values were higher in smokers than in non-smokers, and gingival bleeding was more prevalent in nonsmokers than in smokers.

Nicotine absorption was studied in various commercial products with different nicotine concentrations and different $\mathrm{pH}$ values. It was found that higher $\mathrm{pH}$ products gave more nicotine than low $\mathrm{pH}$ products. It has been shown that nicotine is in the non-ionized form at alkaline $\mathrm{pH}$ and is more easily absorbed in the buccal mucosa. It is not sufficiently absorbed in the ionic form at acidic $\mathrm{pH}$ values. ${ }^{9,19,20}$ In saliva, $\mathrm{pH}$ has been reported to show a rapid and temporary increase after smoking. Other studies report that the $\mathrm{pH}$ value is relatively lower in smokers compared to nonsmokers. ${ }^{21}$ However, the correlation between smoking desire and saliva $\mathrm{pH}$ has not been extensively studied. Our study observed that saliva $\mathrm{pH}$ increased after drinking coffee, but there was no significant change in smoking desire.

There was no statistically significant change between VAS1basal and VAS2 - after coffee, but a statistically significant decrease in VAS3 values after drinking water suggested that smoking desire was decreased. The smoking desire was assessed with VAS, which was previously described in the literature. VAS is a

TABLE 4. $\mathrm{pH}$ and VAS Changes in Smokers

\begin{tabular}{lcc}
\hline & Mean $(\mathrm{SD})$ & $P$ \\
\hline $\mathrm{pH}$ basal-pH after coffee & $6.67( \pm 0.41)-6.93( \pm 0.36)$ & $<.01$ \\
$\mathrm{pH}$ after coffee-pH after water & $6.93( \pm 0.36)-6.85( \pm 0.33)$ & .019 \\
VAS basal-VAS after coffee & $4.73( \pm 3.21)-4.91( \pm 3.08)$ & $>.05$ \\
VAS after coffee-VAS after water & $4.91( \pm 3.08)-3.15( \pm 2.72)$ & $<.01$ \\
\hline
\end{tabular}

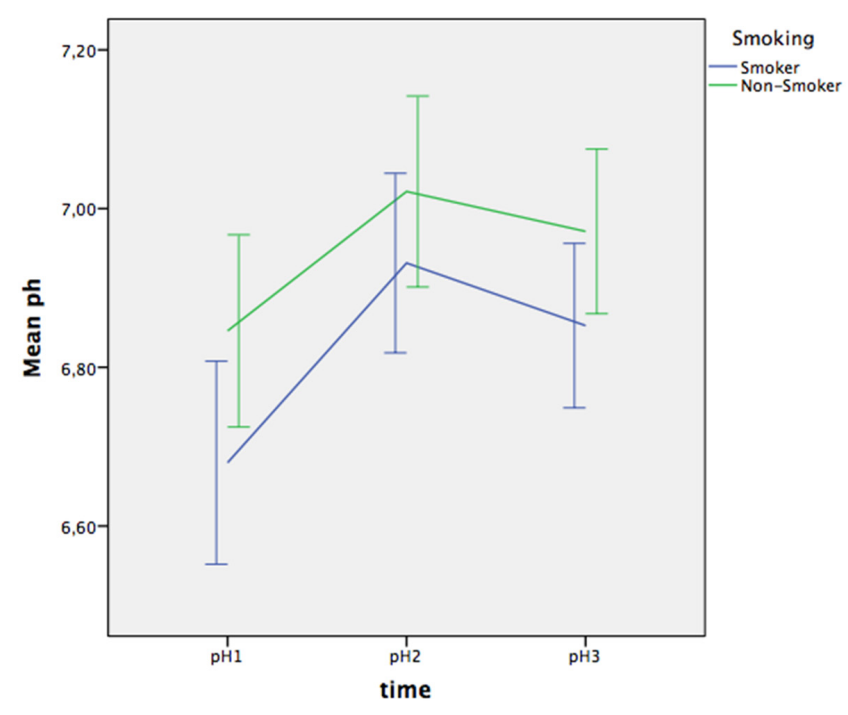

Error bars: $95 \% \mathrm{Cl}$

FIG. 2. The changes of $\mathrm{pH}$ values, basal- $\mathrm{pH} 1$, after coffee- $-\mathrm{pH} 2$, and after water- $\mathrm{pH} 3$, in smokers and non-smokers.

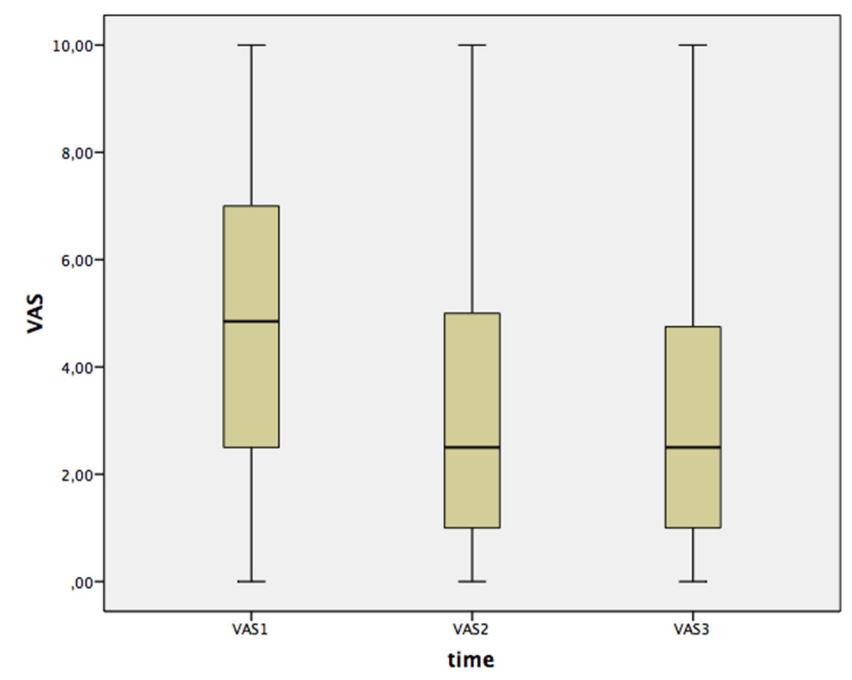

FIG. 3. The changes of VAS values, basal-VAS1, after coffee consumption-VAS2, and after water-VAS3, in smokers. 
method that has been used in previous studies to evaluate smoking desire and is considered valid. ${ }^{17,18}$ As indicated in Table 4, although VAS scores did not change with coffee consumption, a significant change was observed after water consumption decreased in VAS score, which suggests a decrease in smoking desire. These findings indicate that water consumption may reduce smoking desire in smokers; however, this finding merits more research in this area. Our study showed an increase in saliva $\mathrm{pH}$ values after caffeine, and at the same time, an increase in VAS values was found, but it was not found statistically significant. Participants associated this situation with their traditional preference for tea. The factors that trigger nicotine use include stress, daily routine, eating and drinking habits, and caffeine. Caffeine and nicotine interactions can be explained by neurochemical mechanisms. Caffeine is a non-selective antagonist at the level of A1 and A2A receptors. Chronic caffeine exposure has been shown to produce a change in the number and function of central adenosine receptors. Acting as an agonist at $\mathrm{A} 1$ and $\mathrm{A} 2$ receptors, adenosine inhibits the mediated effects of D1 and D2 dopamine receptors. ${ }^{4,22}$ Use of nicotine with caffeine provides the potential for stimulation via the dopaminergic pathway. ${ }^{23}$ studies are reporting that there is no interaction between caffeine and nicotine, and studies reporting that caffeine consumption increases the number of cigarettes smoked. However, epidemiological studies relate co-consumption of caffeine and nicotine after meals and between meals rather than pharmacological effects. It has been reported that smokers consume more caffeine than nonsmokers. ${ }^{24,25}$ In a study by Emurian et al., it was shown that there was more smoking in the 20 min after coffee consumption compared to the $20 \mathrm{~min}$ before. In other studies, it was reported that there is no interaction between caffeine and nicotine and between co-consumption of caffeine and nicotine after meals and between meals rather than pharmacological effects. And also, it was tested that increased dosage of caffeine may alter nicotine intake in smokers. As a result, it has shown an upward trend in cigarette consumption during caffeine consumption and a trend toward higher plasma nicotine levels in the low-dose caffeine group compared to the decaffeinated group. ${ }^{26,27}$

Although our results were not statistically significant, smokers were found to have lower saliva flow rates than non-smokers, similar to the literature. ${ }^{28,29}$ Also, it was shown that smokers' had poor oral hygiene than non-smokers, and tooth loss was higher in smokers than non-smokers. Also, that gingival bleeding was lower in smokers than in non-smokers. Furthermore, previous studies have shown that smokers show more symptoms of periodontal disease than non-smokers. ${ }^{30,31}$ Similar to our results, it was reported that bleeding was reduced in young adult smokers, regardless of plaque and calculus distribution. ${ }^{32}$

Although saliva $\mathrm{pH}$ increased after drinking coffee, its effect on smoking desire could not be shown statistically. However, it can be seen that drinking water lowers saliva $\mathrm{pH}$ values, and the desire to smoke after drinking water decreases. Drinking the appropriate amount of water during the day is a recommended healthy behavior, and regulations in our daily eating and drinking habits are thought to be an important support for smoking cessation treatments. Based on our results, it can be said that quitting smoking is necessary for better oral and dental health. The fact that the results of this crosssectional study we obtained in our single-center cannot be generalized for all smokers is the limitation of this study.

This manuscript was presented as an "oral presentation" at the 22nd International Congress of The Turkish Thoracic Society on April 10-14, 2019, in Antalya, Turkey, and as a "poster discussion" at the European Respiratory Society International Congress from September 28 to October 2, 2019, in Madrid, Spain.

Ethics Committee Approval: Ethics committee approval was received for this study from the Clinical Studies Ethics Committee of Dokuz Eylül University (2018/09-01), and registered at ClinicalTrials.gov (Identifier: NCT04032236).

Patient Consent for Publication: N/A.

Data-sharing Statement: The data that support the findings of this study are available from the corresponding author upon reasonable request.

Author Contributions: Concept - G.Ö.Ş., G.K., B.E., O.K.; Design - G.Ö.Ş., G.K., B.E., O.K.; Supervision - O.K.; Resources - G.Ö.Ş., G.K.; Materials - G.Ö.Ş., G.K.; Data Collection and/or Processing - G.Ö.Ş., G.K.; Analysis and/or Interpretation - G.Ö.Ş., B.E.; Literature Review - G.Ö.Ş., G.K.; Writing - G.Ö.Ş., G.K.; Critical Review - G.Ö.Ş., G.K., B.E., O.K.

Conflict of Interest: The authors have no conflicts of interest to declare.

Funding: This project is supported by DEU Scientific Research Projects Coordination Unit (2019.KB.SAG.028).

\section{REFERENCES}

1. Kurumu Tİ. Turk Sağllk Araştırması. 2020 [cited 2020 01.07.2020]. Available from: https://data.tuik.gov.tr/Bulten/Index?p=Turkiye-Saglik-Arastirmasi-2019-33661.

2. Benowitz NL. Pharmacology of nicotine: addiction, smoking-induced disease, and therapeutics. Annu Rev Pharmacol Toxicol. 2009;49:57-71. [CrossRef]

3. D'Souza MS, Markou A. Neuronal mechanisms underlying development of nicotine dependence: implications for novel smoking-cessation treatments. Addict Sci Clin Pract. 2011;6(1):4-16.

4. Tanda G, Goldberg SR. Alteration of the behavioral effects of nicotine by chronic caffeine exposure. Pharmacol Biochem Behav. 2000;66(1):47-64. [CrossRef]

5. Parvinen T. Stimulated salivary flow rate, $\mathrm{pH}$ and lactobacillus and yeast concentrations in non-smokers and smokers. Scand J Dent Res. 1984;92(4):315-318. [CrossRef]

6. Bergström J, Eliasson S, Dock J. A 10-year prospective study of tobacco smoking and periodontal health. J Periodontol. 2000;71(8):1338-1347. [CrossRef]

7. Pickworth WB, Rosenberry ZR, Gold W, Koszowski B. Nicotine absorption from smokeless tobacco modified to adjust pH. J Addict Res Ther. 2014;5(3):1000184. [CrossRef]

8. Tomar SL, Henningfield JE. Review of the evidence that $\mathrm{pH}$ is a determinant of nicotine dosage from oral use of smokeless tobacco. Tob Control. 1997;6(3):219-225. [CrossRef]

9. Ciolino LA, McCauley HA, Fraser DB, Wolnik KA. The relative buffering capacities of saliva and moist snuff: implications for nicotine absorption. J Anal Toxicol. 2001;25(1):15-25. [CrossRef]

10. Laine M, Tenovuo J, Lehtonen OP, et al. Pregnancy-related changes in human whole saliva. Arch Oral Biol. 1988;33(12):913-917. [CrossRef]

11. Laine M, Pienihäkkinen K. Salivary buffer effect in relation to late pregnancy and postpartum. Acta Odontol Scand. 2000;58(1):8-10. [CrossRef]

12. Heatherton TF, Kozlowski LT, Frecker RC, Fagerström KO. The Fagerström test for nicotine dependence: a revision of the Fagerström Tolerance Questionnaire. $\mathrm{Br} J$ Addict. 1991;86(9):1119-1127. [CrossRef]

13. Uysal MA, Kadakal F, Karşidağ C, et al. Fagerstrom test for nicotine dependence: reliability in a Turkish sample and factor analysis. Tuberk Toraks. 2004;52(2):115-121.

14. Aslan Dilek BN, Nesrin D, Oğuz K, et al. Tütün Bağımlılı̆̆ ile Mücadele El Kitabl. TC Sağlık Bakanlı̆̆ $; 2010: 82$. 
15. Silness J, Loe H. Periodontal disease in pregnancy II. Correlation between oral hygiene and periodontal condition. Acta Odontol Scand. 1964;22:121-135. [CrossRef]

16. World Health Organization. Oral Health Surveys: Basic Methods. Geneva: World Health Organization; 2013.

17. Heishman SJ, Singleton EG, Moolchan ET. Tobacco craving questionnaire: reliability and validity of a new multifactorial instrument. Nicotine Tob Res. 2003;5(5):645-654. [CrossRef]

18. Heishman SJ, Lee DC, Taylor RC, Singleton EG. Prolonged duration of craving, mood, and autonomic responses elicited by cues and imagery in smokers: effects of tobacco deprivation and sex. Exp Clin Psychopharmacol. 2010;18(3):245-256. [CrossRef]

19. Hildreth SB, Gehman EA, Yang H, et al. Tobacco nicotine uptake permease (NUP1) affects alkaloid metabolism. Proc Natl Acad Sci USA. 2011;108(44):18179-18184. [CrossRef]

20. Richter P, Hodge K, Stanfill S, Zhang L, Watson C. Surveillance of moist snuff: total nicotine, moisture, $\mathrm{pH}$, un-ionized nicotine, and tobacco-specific nitrosamines. Nicotine Tob Res. 2008;10(11):1645-1652. [CrossRef]

21. Benowitz NL, Hukkanen J, Jacob P, 3rd. Nicotine chemistry, metabolism, kinetics and biomarkers. Handb Exp Pharmacol. 2009;192(192):29-60. [CrossRef]

22. Pullishery F, Panchmal GS, Siddique S. Salivary thiocyanate, uric acid and $\mathrm{pH}$ as biomarkers of periodontal disease in tobacco users and non-users - an in-vitro study. J Clin Diagn Res. 2015;9(7):ZC47-ZC50. [CrossRef]

23. Gasior M, Shoaib M, Yasar S, Jaszyna M, Goldberg SR. Acquisition of nicotine discrimination and discriminative stimulus effects of nicotine in rats chronically exposed to caffeine. J Pharmacol Exp Ther. 1999;288(3):1053-1073.
24. El Yacoubi M, Ledent C, Ménard JF, et al. The stimulant effects of caffeine on locomotor behaviour in mice are mediated through its blockade of adenosine A(2A) receptors. Br J Pharmacol. 2000;129(7):1465-1473. [CrossRef]

25. Treloar HR, Piasecki TM, McCarthy DE, Baker TB. Relations Among caffeine consumption, smoking, smoking urge, and subjective smoking reinforcement in daily life. J Caffeine Res. 2014;4(3):93-99. [CrossRef]

26. Emurian HH, Nellis MJ, Brady JV, Ray RL. Event time-series relationship between cigarette smoking and coffee drinking. Addict Behav. 1982;7(4):441-444. [CrossRef]

27. Treur JL, Taylor AE, Ware JJ, et al. Associations between smoking and caffeine consumption in two European cohorts. Addiction. 2016;111(6):1059-1068. [CrossRef]

28. Khemiss M, Ben Khelifa M, Ben Saad H. Preliminary findings on the correlation of saliva $\mathrm{pH}$, buffering capacity, flow rate and consistency in relation to waterpipe tobacco smoking. Libyan J Med. 2017;12(1):1289651. [CrossRef]

29. Fenoll-Palomares C, Muñoz Montagud JV, Sanchiz V, et al. Unstimulated salivary flow rate, $\mathrm{pH}$ and buffer capacity of saliva in healthy volunteers. Rev Esp Enferm Dig. 2004;96(11):773-783. [CrossRef]

30. Bergström J, Eliasson S. Noxious effect of cigarette smoking on periodontal health. J Periodont Res. 1987;22(6):513-517. [CrossRef]

31. Bergström J, Eliasson S. Cigarette smoking and alveolar bone height in subjects with a high standard of oral hygiene. J Clin Periodontol. 1987;14(8):466-469. [CrossRef]

32. Müller HP, Stadermann S, Heinecke A. Bleeding on probing in smokers and nonsmokers in a steady state plaque environment. Clin Oral Investig. 2001;5(3):177-184. [CrossRef] 